\title{
Baby, remember my name!
}

DOI:

10.1016/j.fbp.2009.08.001

Link to publication record in Manchester Research Explorer

\section{Citation for published version (APA):}

Campbell, G. M., \& Vadlani, P. (2009). Baby, remember my name! Food and Bioproducts Processing:

Transactions of the Institution of of Chemical Engineers, Part C, 87(3), 163.

https://doi.org/10.1016/j.fbp.2009.08.001

\section{Published in:}

Food and Bioproducts Processing: Transactions of the Institution of of Chemical Engineers, Part C

\section{Citing this paper}

Please note that where the full-text provided on Manchester Research Explorer is the Author Accepted Manuscript or Proof version this may differ from the final Published version. If citing, it is advised that you check and use the publisher's definitive version.

\section{General rights}

Copyright and moral rights for the publications made accessible in the Research Explorer are retained by the authors and/or other copyright owners and it is a condition of accessing publications that users recognise and abide by the legal requirements associated with these rights.

\section{Takedown policy}

If you believe that this document breaches copyright please refer to the University of Manchester's Takedown Procedures [http://man.ac.uk/04Y6Bo] or contact uml.scholarlycommunications@manchester.ac.uk providing relevant details, so we can investigate your claim.

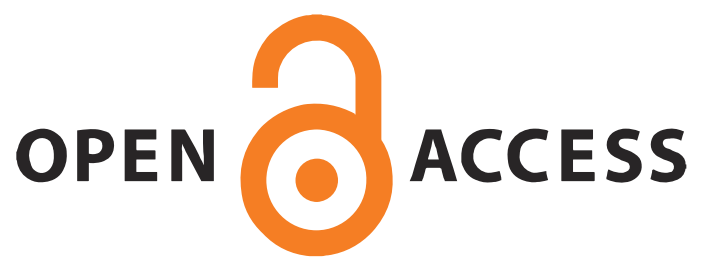




\section{Editorial}

\section{Baby, remember my name!}

"What is fame? An empty bubble; Gold? A transient, shining trouble." James Grainger

The common philosophical, sociological and historical models of Science combine to present an idealistic view of dispassionate, rational scientists who serve the objective search for truth. This ideology of Science is constructed by focussing on the process of science as presented, while omitting consideration of the motives and needs of the scientists ostensibly pursuing this process; it is thus a "flawed ideal" (Broad and Wade, 1982). Underneath their training and behind their professionalism, scientists are people, and are not immune to the values, ambitions, noble ideals, base contradictions, pressures and temptations common to man; their actions and the motivations driving these can be viewed and interpreted against this reality.

Fame and recognition are powerful motivators and underpin much ambition, including scientific ambition. They also serve to attract the requisite components for a sustainable scientific career, which is a legitimate pragmatic consideration for modern career scientists, along with material rewards and benefits. The observation also applies to engineer-scientists-researchers in the engineering disciplines who operate in comparable situations to pure scientists, but perhaps with the pure search for truth modulated by an inclination towards practical application and benefit. The personal and pragmatic motivations for fame and recognition remain, and they remain legitimate. Fame is a powerful motivator, and whatever its potential pitfalls, well motivated research engineers engaging creatively with science to benefit society are "a good thing", and they should be recognised and rewarded.

Engineers are, however, less likely than scientists to achieve fame. (The few exceptions that spring to mind do not remove the probabilistic essence of this argument. If we insert "Chemical" at the start, then the assertion is probably beyond contention!) But Isaac Asimov observed "Science can amuse and fascinate us all - but it is engineering that changes the world." And we live in a world that has changed, and that needs to change again. The world inherited from the 20 th century has as its predominant feature a depleted energy resource that has been processed into a climate change problem. The 'world' as 'Gaia' has changed. The political, industrial and social 'world' needs to change in response. And now engineers, particularly chemical engineers, have an opportunity and a responsibility to play their part - and maybe even make a name for themselves.

This special topic issue addresses the theme "Biorefinery Innovations", as a complement to the companion special issue "Biorefinery Integration" in the sister publication Chemical Engineering Research and Design. In contrast with other engineers, chemical engineers tend not to produce "widgets" of the sort that can be tangibly recognised and appreciated in line with concepts of fame; they seldom feature on the news or as heroes of the hour in popular film culture. Nevertheless, it is probably the case that "innovations" are more likely to lead to recognition than, say, "evaluations". Thus, this issue, with its focus on innovations, may appear on the face of it more auspicious than its companion. But in either case, the motivation for the work presented in these two issues is to help to change the world, in the face of the greatest challenge the world has ever faced. Failure to do so means an end to fame of any sort (except perhaps a kind of poignant cosmic notoriety). One hopes that the names featured in this issue and in its sister will go on to ever greater achievement and influence in relation to the threat of global catastrophe, and that there will be children's children to look back through these pages and be thankful for (inter alia) chemical engineers.

\section{Reference}

Broad, W. and Wade, N., (1982). Betrayers of the Truth: Fraud and Deceit in the Halls of Science. (Century Publishing, London, UK).

Grant M. Campbell a,* Praveen Vadlani ${ }^{b}$

${ }^{a}$ University of Manchester, School of Chemical Engineering and Analytical Science, PO Box 88, Manchester M60 1QD, United Kingdom

${ }^{b}$ Department of Grain Science \& Industry 201 Shellenberger Hall Manhattan, KS 66506, USA

* Corresponding author.

E-mail address: grant.campbell@manchester.ac.uk (G.M. Campbell)

0960-3085/\$ - see front matter Crown Copyright @ 2009 Published by Elsevier B.V. All rights reserved. doi:10.1016/j.fbp.2009.08.001 